\title{
Quality indicators in Higher Education: analysis of psychosocial factors of students
}

\author{
Ana Merchán-Clavellino ${ }^{*}$, Concha Martínez-García², María Pilar Salguero-Alcañiz ${ }^{3}$ \\ Susana Paíno-Quesada ${ }^{3}$ y Jose Ramón Alameda-Bailén ${ }^{3}$
}

\author{
'Departamento de Psicología de la Universidad de Cádiz \\ ${ }^{2}$ Departamento de Psicología Social, Evolutiva y de la Educación \\ ${ }^{3}$ Departamento de Psicología Clínica y Experimental de la Universidad de Huelva
}

\begin{abstract}
The objective is to determine the influence of substance consumption, emotional intelligence, and academic context on the two main indicators of the quality of university education: academic achievement and degree of satisfaction. Participants in the study were 202 students $(82.2 \%$ female; mean age 21.83 years). Data were collected with a questionnaire including six parts: sociodemographic data, substance consumption, levels of satisfaction, academic context, academic performance (calculated by averaging the grades of all exams completed) and the Trait Meta Mood Scale-24 to assess emotional intelligence. Data were analyzed through hierarchical multiple regression. The results reveal that prior achievement and satisfaction with academic advances explain $34.9 \%$ of academic achievement. However, the predictor variables of satisfaction are different: academic context (academic course and hours of study), emotional intelligence (clarity and repair), and substance consumption (hallucinogenic substances consumed in the last 12 months). All of them explained $23.1 \%$. It is concluded that the personal determinants of university students should be dealt with transversally in order to affect achievement and satisfaction, thus improving the quality of the university system.
\end{abstract}

Keywords: Academic achievement, University satisfaction, Higher education, Emotional intelligence, Academic context.

\section{Indicadores de calidad en la Educación Superior: análisis de los factores psicosociales de los estudiantes.}

Resumen: El objetivo de este trabajo es conocer la influencia que tienen el consumo de sustancias, la inteligencia emocional y el contexto académico sobre los dos principales indicadores de la calidad de la enseñanza universitaria: rendimiento académico y grado de satisfacción. En el estudio participan 202 estudiantes (82.2\% mujeres; edad media 21.83 años). Para la recogida de datos se empleó un cuestionario dividido en seis partes: datos sociodemográficos, consumo de sustancias, nivel de satisfacción, contexto académico, rendimiento académico (calculando la nota media de los exámenes presentados) y el TMM-24 para evaluar la inteligencia emocional. El análisis de datos consiste en una regresión múltiple jerárquica. Los resultados ponen de manifiesto que el rendimiento previo y la satisfacción sobre los avances académicos explican un 34.9\% del rendimiento académico. Por otra parte, las variables predictivas para la satisfacción son de distinta naturaleza: contexto académico (curso académico y horas de estudio), inteligencia emocional (claridad y reparación) y consumo de sustancias (sustancias alucinógenas consumidas en los últimos 12 meses). Todas ellas alcanzan a explicar el 23,1\%. Concluimos que, los determinantes personales del alumnado universitario, deben trabajarse de forma transversal, para que tengan efecto sobre el rendimiento y la satisfacción, mejorando así, la calidad del sistema universitario.

Palabras clave: Rendimiento académico, Satisfacción universitaria, Estudiantes universitarios, Inteligencia emocional, Contexto académico.

Recibido: 22/05/2018 - Aceptado: 2/10/2018 - Avance online: 17/10/2018

*Correspondencia: Ana Merchán Clavellino.

Departamento de Psicología de la Universidad de Cádiz.

C.P: 11519, Puerto Real, Cádiz, España.

E-mail: ana.merchan@uca.es

Merchán-Clavellino, A., Martínez-García, C., Salguero-Alcañiz, M.P., Paíno, S. y Alameda-Bailén, J.R. (2019). Quality indicators in higher education: analysis of psychosocial factors of students. Journal of Psychology and Education, 14(1), 27-26. https://doi.org/10.23923/rpye2019.01.169
There is currently some consensus to consider academic achievement and student's satisfaction as the main indicators of the quality of university education (Tejedor, 2003).

1699-9517/@ 2019 Asociación Científica de Psicología y Educación (ACIPE).

Publicado por Consejo General de Colegios Oficiales de Psicólogos, España. Este es

un artículo Open Access bajo la CC BY-NC-ND licencia (http://creativecommons.org/

licencias/by-nc-nd/4.0/). 
Three types of factors are thought to influence academic achievement (Garbanzo, 2007): personal factors (class attendance, skills, psychological well-being, etc.), social factors (social differences, family environment, parents' educational level, etc.), and institutional factors (choice of degree, student environment, student-teacher relationship, etc.).

On another hand, students' satisfaction refers to their positive consideration of the results and educational experiences, as a function of the attention received to meet their needs and achievement expectations (Gento \& Vivas, 2003; Weerasinghe, Lalitha, \& Fernando, 2017). Thus, satisfaction is related to factors such as tutorial attention, intrinsic motivation, teacher's attitude, academic environment, use of interactive methodologies, and academic achievement and expectations (González-Arias, Carabantes-Olivares, \& Muñoz-Carreño, 2016; Tessema, Ready, \& Yu, 2012).

As can be observed, among the determinants of quality (assessed by means of the indicators achievement and satisfaction), it is unusual to study the incidence of personal factors, which is why we focus on them in this work. Among the students' personal factors, we distinguish three groups:

Substance consumption. There is evidence that consumption of psychoactive substances could be related to low academic achievement (Caso-Niebla \& Hernández-Guzmán, 2007; Pritchard \& Wilson, 2003; Tejedor, 2003) and to institutional dissatisfaction in the university population (Moral, Rodríguez \& Ovejero, 2010).

Emotional intelligence (EI), understood as the skill to identify, express, understand, and adequately manage one's own and others' emotions, it has positive effects on personal adaptation in different life areas, among them, the educational area (Anadón, 2006; Fernández-Berrocal \& Ruíz, 2008; Mestre, Gutiérrez, Guerrero, \& Guil, 2017; Pérez \& Castejón, 2007). However, the relation between $\mathrm{El}$ and academic achievement is controversial.
On the one hand, some works report a direct relation between the two concepts (Gil-Olarte, Palomera \& Bracket, 2006; Pérez \& Castejón, 2007) whereas, in other studies, the relation is considered indirect, that is, the effect of $\mathrm{El}$ on academic achievement is modulated by other variables such as well-being or psychological balance (Extremera \& Fernández-Berrocal, 2003; Ferragut \& Fierro, 2012; Serrano \& Andreu, 2016). In any event, in some works that studied the relation between $\mathrm{El}$ and university satisfaction, no relation was observed in a general sense, but there was a relation in specific areas, for example, in nursing students (Grace, 2004) and in online universities (Thompson, 2013).

Academic context, understood as the set of variables describing the circumstances in which the teaching-learning process occurs, for example, class attendance, prior performance, hours of study, etc...(Johnson \& Buck, 1995). These variables can have an impact on academic achievement and satisfaction, influencing university quality (Hernando, Oliva \& Pertegal, 2012). Accordingly, some studies reveal that class attendance and prior performance are two important predictors of academic achievement whereas hours of study have less explanatory potential (Álvarez \& López, 2011 ; Garbanzo, 2007; García, Alvarado, \& Jiménez, 2000; McKenzie \& Schweitzer, 2001).

The goal of the present investigation is to study the prediction of academic achievement and university satisfaction, as indicators of quality, through these personal variables. For this purpose, we focused on the analysis of the following variables: Consumption of psychoactive substances: classified as a function of their effects on the central nervous system, Emotional intelligence and Academic context: Academic course, hours of study, absenteeism and prior performance.

According to the literature, we hypothesize that emotional intelligence, the consumption of substances as variables in the student's context, will predict the quality of higher education. So quality indicators will be positively related 
to emotional intelligence, hours of study, prior achievements and the academic course. And they will be negatively related to substance use and absenteeism.

\section{METHODOLOGY}

\section{PARTICIPANTS}

The sample is made up of 202 students with a mean age of $21.83(S D=6.39)$, the majority females (82.2\%), who are studying psychology subjects in different degrees of the University of Huelva (Spain): Psychology, Humanities, Labor Relations and Human Resources. Of these participants, $51.98 \%$ are first-year students, $33.66 \%$ are second-year students, $3.96 \%$ are in their third year, and $10.4 \%$ are fourth-year students.

\section{INSTRUMENTS}

The questionnaire contained the following six parts:

Sociodemographic data: Age, sex, and work situation of the participants.

Substance consumption: substances were classified into three groups according to their effects on the central nervous system; depressants (alcohol, benzodiazepine, illegal methadone, other opiates and heroin), stimulants (cocaine, freebase cocaine, tobacco, and amphetamines), and hallucinogens (cannabis, designer drugs, and other hallucinogens such as LSD, phencyclidine, psilocybin, peyote, and mushrooms). Participants responded to 36 items about the quantity (according to the number of cigars for tobacco and cannabis, glasses of alcohol, pills or grams) and the frequency of consumption in the last 30 days and in the last 12 months. It has been prepared ad hoc, based on the European Adaptation of a Multidimensional Assessment Instrument for Drug and Alcohol Dependence (EuropAsi) (Bobes, González, Sáiz, \& Bousoño, 1996).
Levels of satisfaction: 8 items, rated on a six-point Likert-type scale (ranging from 0 , nothing satisfied, to 5 , very satisfied), requested information about the degree in general, the teaching methodology, the assessment method, the professors' quality, professor-student relationships, academic progress, the university services, and the university environment. It has been prepared ad hoc. In our sample, Cronbach's alpha for total scale was $\alpha=.79$.

Academic context: 4 items referred to the entrance examination grade (values from o to 14), academic course, hours of weekly study, absenteeism (days per semester).

Academic achievement: They were asked about the grades obtained (excluding the subjects for which the participant did not take the exam). Academic performance was calculated by averaging the grades of all exams completed (ranging from 0 to 10).

Emotional intelligence was assessed by means of the Trait Meta Mood Scale-24 (Salovey, Mayer, Goldman, Turvey, \& Palfai, 1995; adaptation by Fernández-Berrocal et al., 1998). This scale contains 24 items, rated on a 5-point Likert scale ranging from 1 (strongly disagree) to 5 (strongly agree). It has three dimensions, with 8 items each: Attention (identifying one's own and others' emotions and knowing how to express them), Clarity (understanding emotions), and Repair (capacity to manage emotions). In our sample, Cronbach's alpha for each dimension was as follows: Emotional Attention $\alpha=.88$, Emotional Clarity $\alpha=.90$, and Emotional Repair $\alpha=.87$.

\section{PROCEDURE}

Data were collected through a questionnaire, either online or in person. For the telematic mode, we used the Moodle virtual teaching environment of the University of Huelva. For onsite registration, we used the same questionnaire in paper format. In all cases, the participants 
sign an informed consent and completed the questionnaire voluntarily and anonymously.

\section{DATA ANALYSIS}

Data were analyzed with the SPSS 20 statistical package. In the descriptive analysis, means and standard deviations were calculated for the quantitative variables, and percentages were obtained for the qualitative ones. To analyze the effect of the independent variables on academic achievement and university satisfaction, we used Pearson correlations for the quantitative variables, Student's t-test for independent samples for the quantitative variables, and ANOVA for the variable academic course. We performed multiple linear regression analysis for each criterion variable: academic achievement and university satisfaction.

\section{RESULTS}

\section{DESCRIPTIVE ANALYSIS}

Firstly, we analyzed the effects of the qualitative variables (sex, work situation, and academic course) on the indicators of quality: achievement and satisfaction (Table 1).

The results revealed statistically significant differences in university satisfaction as a function of course, $F(3,201)=3.14, p=$ .027. Significant differences in satisfaction between first- and second-year students were confirmed through Bonferroni adjustment $(p<$ .05), indicating less satisfaction in the secondyear students.

Table 2 presents the descriptive analyses of the quantitative variables: age, emotional intelligence, academic context, and satisfaction.

\begin{tabular}{|c|c|c|c|c|c|c|c|}
\hline \multicolumn{8}{|c|}{$\begin{array}{l}\text { Table } 1 \\
\text { and descriptive statistics, as a function of academic } \\
\text { and university satisfaction }\end{array}$} \\
\hline & & \multirow[b]{2}{*}{$n$} & \multirow[b]{2}{*}{$\%$} & \multicolumn{2}{|c|}{ Academic achievement } & \multicolumn{2}{|c|}{ University satisfaction } \\
\hline & & & & $M$ & $S D$ & $M$ & $S D$ \\
\hline \multirow{2}{*}{ Sex } & Male & 36 & 17.82 & 5.99 & 1.57 & 3.49 & 0.52 \\
\hline & Female & 166 & 82.18 & 6.41 & 1.19 & 3.66 & 0.56 \\
\hline \multirow{2}{*}{ Is working } & No & 150 & 74.26 & 6.35 & 1.29 & 3.63 & 0.54 \\
\hline & Yes & 52 & 25.74 & 6.28 & 1.24 & 3.65 & 0.62 \\
\hline \multirow{4}{*}{ Course } & $1 s t$ & 105 & 51.98 & 6.30 & 1.21 & 3.74 & 0.53 \\
\hline & 2nd & 68 & 33.66 & 6.22 & 1.34 & 3.51 & 0.55 \\
\hline & $3 r d$ & 8 & 3.96 & 6.26 & 1.06 & 3.64 & 0.49 \\
\hline & 4th & 21 & 10.40 & 6.86 & 1.41 & 3.46 & 0.60 \\
\hline
\end{tabular}

Table 2

Descriptive statistics of the age, emotional intelligence, academic contextual variables, and university satisfaction

\begin{tabular}{|c|c|c|c|}
\hline Variables & & $M$ & $S D$ \\
\hline Age (years) & & 21.83 & 6.39 \\
\hline \multirow{3}{*}{ Emotional intelligence } & Attention & 27.77 & 6.02 \\
& Clarity & 28.67 & 5.43 \\
\hline \multirow{2}{*}{ Academic context } & Repair & 28.72 & 5.99 \\
& Entrance examination grade & 7.45 & 1.41 \\
\hline University satisfaction & Hours of study & 11.57 & 8.92 \\
& Absenteeism & 5.07 & 11.99 \\
\hline
\end{tabular}


Table 2 (Continuation)

Descriptive statistics of the age, emotional intelligence, academic contextual variables, and university satisfaction

\begin{tabular}{|c|c|c|c|}
\hline Variables & & $M$ & $S D$ \\
\hline \multirow{3}{*}{ University satisfaction } & Faculty quality & 3.53 & 0.71 \\
& Professor-student relations & 3.71 & 0.85 \\
& Academic progress & 3.86 & 0.89 \\
& University services & 3.35 & 1.07 \\
\hline
\end{tabular}

\section{CORRELATION ANALYSIS}

With regard to substance consumption, the results revealed that the highest levels of consumption were observed for alcohol $(M$ $=2.92, S D=1.67)$, nicotine $(M=2.42$, $S D=4.97)$, and cannabis $(M=0.41, S D=$ 0.74 ), and no consumption of heroin, illegal methadone, freebase cocaine, or other drugs were observed (Table 3).
Pearson coefficient correlation was calculated for the quantitative variables (age, emotional intelligence, academic context, substance consumption, and satisfaction) to determine which variables are more closely related and thus, include them in the regression models. We highlight the following results of the correlations (Table 4):

Table 3

Substances consumed $(\%)$ and consumption frequency in the past month and past year

\begin{tabular}{|c|c|c|c|c|c|c|c|c|c|}
\hline & & \multicolumn{4}{|c|}{ Last 30 days } & \multicolumn{4}{|c|}{ Last 12 months } \\
\hline & & \multicolumn{2}{|c|}{ Consumption } & \multicolumn{2}{|c|}{ Frequency* } & \multicolumn{2}{|c|}{ Consumption } & \multicolumn{2}{|c|}{ Frequency* } \\
\hline & & Yes \% & No $\%$ & $M$ & SD & Yes \% & No $\%$ & $M$ & SD \\
\hline \multirow{3}{*}{ Depressants } & Alcohol & 79.7 & 20.3 & 3.62 & 4.19 & 90.6 & 9.4 & 48.11 & 55.46 \\
\hline & Benz. & 7.4 & 92.6 & 0.80 & 4.35 & 10.4 & 89.6 & 6.89 & 44.23 \\
\hline & Total & & & 4.42 & 5.76 & & & 55.00 & 67.70 \\
\hline \multirow{4}{*}{ Stimulants } & Nicotine & 33.2 & 66.8 & 6.27 & 11.48 & 38.6 & 61.4 & 70.75 & 132.56 \\
\hline & Cocaine & 0 & 100 & 0 & 0 & 1.5 & 98.5 & 0.03 & 0.29 \\
\hline & Amph. & 0 & 100 & 0 & 0 & 1.5 & 98.5 & 0.01 & 0.12 \\
\hline & Total & & & 6.27 & 11.48 & & & 70.80 & 132.61 \\
\hline \multirow{4}{*}{ Hallucinogens } & Cannabis & 18.3 & 81.7 & 1.05 & 3.98 & 33.2 & 66.8 & 11.54 & 48.10 \\
\hline & Designer $\mathrm{D}$. & 0 & 100 & 0 & 0 & 1.5 & 98.5 & 0.02 & 0.21 \\
\hline & Other & 0.5 & 99.5 & 0 & 0.07 & 3 & 97 & 0.05 & 0.38 \\
\hline & Total & & & 1.06 & 3.98 & & & 11.62 & 48.20 \\
\hline \multicolumn{10}{|c|}{$\begin{array}{l}\text { Note: Benz. = Benzodiazepines, Amph. = Amphetamine, Designer D. = Designer drugs, Other = Other hallucinogens } \\
\text { * Frequency: alcohol = number of drinks, nicotine and cannabis = number of cigarettes, benz = number of pills and for the } \\
\text { other substances = grams. }\end{array}$} \\
\hline
\end{tabular}




\section{Table 4}

Pearson correlations between emotional intelligence dimensions, academic context, university satisfaction, substance consumption and age

\begin{tabular}{|c|c|c|c|c|c|c|c|c|c|c|c|c|c|c|c|c|c|}
\hline & & 1 & 2 & 3 & 4 & 5 & 6 & 7 & 8 & 9 & 10 & 11 & 12 & 13 & 14 & 15 & 16 \\
\hline 1 & Attention & & & & & & & & & & & & & & & & \\
\hline 2 & Clarity & .105 & & & & & & & & & & & & & & & \\
\hline 3 & Repair & -.09 & $.288^{* *}$ & & & & & & & & & & & & & & \\
\hline 4 & Prior perform. & $.162^{\star}$ & .126 & -.046 & & & & & & & & & & & & & \\
\hline 5 & Hours study & -.067 & .119 & .134 & .017 & & & & & & & & & & & & \\
\hline 6 & $\begin{array}{l}\text { Absenteeism } \\
\text { (days) }\end{array}$ & -.054 & -.086 & -.009 & -.12 & -.134 & & & & & & & & & & & \\
\hline 7 & Achievement & .019 & .119 & .022 & $.497^{* *}$ & .128 & $-.218^{* \prime}$ & & & & & & & & & & \\
\hline 8 & Satisfaction & -.083 & $.291^{* *}$ & $.257^{* *}$ & .066 & $.297^{* *}$ & -.137 & $.151^{*}$ & & & & & & & & & \\
\hline 9 & D-F30 & .087 & -.085 & .013 & $-.166^{*}$ & -.129 & $.190^{* *}$ & -.081 & $-.166^{*}$ & & & & & & & & \\
\hline 10 & D-F12 & .115 & -.096 & .028 & -.113 & -.063 & $.165^{*}$ & -.048 & -.104 & $.840^{* *}$ & & & & & & & \\
\hline 11 & S-F30 & .085 & -.054 & -.133 & .029 & .047 & -.057 & -.03 & -.013 & $.233^{* *}$ & $.212^{* *}$ & & & & & & \\
\hline 12 & S-F12 & .081 & -.052 & $-.152^{*}$ & -.015 & .068 & -.05 & -.012 & .024 & $.233^{* *}$ & $.218^{* *}$ & $.975^{* *}$ & & & & & \\
\hline 13 & Hal-F30 & .049 & .012 & -.078 & -.108 & .042 & $.174^{*}$ & -.078 & -.104 & $.164^{\circ}$ & $.150^{*}$ & $.299^{* *}$ & $.295^{* *}$ & & & & \\
\hline 14 & Hal-F12 & .041 & -.013 & -.116 & -.082 & .025 & $.218^{* *}$ & -.066 & $-.143^{*}$ & $.216^{* *}$ & $.203^{+*}$ & $.269^{* *}$ & $.281^{* *}$ & $.934^{* *}$ & & & \\
\hline 15 & Drinks & .108 & .08 & -.062 & $-.153^{*}$ & -.068 & .064 & -.007 & -.038 & .063 & $.139^{*}$ & .05 & .047 & .106 & .051 & & \\
\hline 16 & Joints & .094 & .058 & -.044 & -.076 & -.021 & 111. & -.027 & -.065 & $.195^{* *}$ & $.236^{* *}$ & $.359^{* *}$ & $.376^{*+}$ & $.636^{* *}$ & $.620^{* *}$ & $.254^{* *}$ & \\
\hline 17 & Cigarettes & .092 & -.051 & -.121 & -.005 & .01 & -.051 & -.039 & -.027 & $.306^{* *}$ & $.313^{* *}$ & $.757^{* *}$ & $.764^{* *}$ & $.143^{\circ}$ & .135 & .07 & $.284^{*}$ \\
\hline 18 & Age & -.084 & -.043 & .123 & $-.280^{* *}$ & .031 & .055 & $-.161^{*}$ & -.027 & $.316^{* *}$ & $.252^{* *+}$ & -.005 & .009 & -.039 & -.024 & $-.214^{\prime \prime}$ & -.055 \\
\hline \multicolumn{18}{|c|}{$\begin{array}{l}\text { Note: Prior Perform = Prior performance; D-F30 = depressants frequency last } 30 \text { days; D-F12 = depressants frequency last } 12 \text { months; } \\
\text { S-F30 = stimulants frequency last } 30 \text { days; S-F12 = stimulants frequency last } 12 \text { months; Hal-F30 = hallucinogens frequency last } 30 \text { days; } \\
\text { Hal-F12 = hallucinogens frequency last } 12 \text { months. } \\
{ }^{*} p<.05 \text { (two-tailed). }{ }^{* *} p<.01 \text { (two-tailed) }\end{array}$} \\
\hline
\end{tabular}

Positive correlations were observed between academic achievement, prior performance (entrance examination grade) $(r=.497 ; p$ $<.001)$, and total satisfaction $(r=.151 ; p$ $=.032$ ). Of the different aspects included in satisfaction, academic achievement correlated positively with assessment methods $(r=.150 ; p=.033)$ academic progress $(r$ $=.348 ; p<.001)$ and satisfaction with the degree $(r=.180 ; p=.010)$. And negative correlations were observed between academic achievement with age $(r=-.161 ; p=.022)$ and absenteeism ( $r=-.218 ; p=.002)$.

Within El, positive correlations were observed between the dimensions of Clarity $(r$ $=.291 ; p<.001)$ and Repair $(r=.257 ; p$ $<.001)$ and total satisfaction. And according to the academic context, positive correlations were observed between hours of study with total satisfaction $(r=.297 ; p<.001)$.

And lastly, regarding substance consumption, a negative correlation was found between satisfaction and consumption, especially, consumption of depressants at the short term ( $r=-.166 ; p=.018)$. and hallucinogens at the long-term $(r=-.143 ; p$ $=.043)$.

\section{PREDICTIVE ANALYSIS}

On the basis of the results of the correlations, we performed step-wise multiple regression analysis for academic achievement and university satisfaction (Table 5). 
Table 5

Multiple regression analysis for the criterion variables academic achievement and university satisfaction

\begin{tabular}{|c|c|c|c|c|c|c|c|}
\hline \multicolumn{8}{|c|}{ Academic achievement } \\
\hline Model & Predictor variables & $R^{2}$ & $F(g l)$ & $p$ & $\beta$ & $t$ & $p$ \\
\hline \multirow[t]{2}{*}{ Step 1} & & .247 & $\begin{array}{l}65.72 \\
(1,201)\end{array}$ & $<.001$ & & & \\
\hline & $\begin{array}{l}\text { Entrance examination } \\
\text { grade }\end{array}$ & & & & .497 & 8.11 & $<.001$ \\
\hline \multirow[t]{3}{*}{ Step 2} & & .349 & $\begin{array}{l}53.25 \\
(2,201)\end{array}$ & $<.001$ & & & \\
\hline & $\begin{array}{l}\text { Entrance examination } \\
\text { grade }\end{array}$ & & & & .478 & 8.34 & $<.001$ \\
\hline & $\begin{array}{l}\text { Satisfaction w. } \\
\text { advances }\end{array}$ & & & & .319 & 5.56 & $<.001$ \\
\hline \multicolumn{8}{|c|}{ University satisfaction } \\
\hline Model & Predictor variables & $R^{2}$ & $F(g l)$ & $p$ & $\beta$ & $t$ & $p$ \\
\hline \multirow[t]{2}{*}{ Step 1} & & .088 & $\begin{array}{c}19.34 \\
(1,201)\end{array}$ & $<.001$ & & & \\
\hline & Hours of study & & & & .297 & 4.40 & $<.001$ \\
\hline \multirow[t]{3}{*}{ Step 2} & & .154 & $\begin{array}{c}18.15 \\
(2,201)\end{array}$ & $<.001$ & & & \\
\hline & Hours of study & & & & .266 & 4.052 & $<.001$ \\
\hline & Clarity & & & & .259 & 3.945 & $<.001$ \\
\hline \multirow[t]{4}{*}{ Step 3} & & .185 & $\begin{array}{l}15.01 \\
(3,201)\end{array}$ & $<.001$ & & & \\
\hline & Hours of study & & & & .262 & 4.051 & $<.001$ \\
\hline & Clarity & & & & .265 & 4.099 & $<.001$ \\
\hline & Course & & & & -.176 & -2.74 & .007 \\
\hline \multirow[t]{5}{*}{ Step 4} & & .212 & $\begin{array}{l}13.57 \\
(4,201)\end{array}$ & $<.001$ & & & \\
\hline & Hours of study & & & & .244 & 3.811 & $<.001$ \\
\hline & Clarity & & & & .218 & 3.282 & .001 \\
\hline & Course & & & & -.185 & -2.927 & .004 \\
\hline & Repair & & & & .173 & 2.597 & .01 \\
\hline \multirow[t]{6}{*}{ Step 5} & & .231 & $\begin{array}{l}11.75 \\
(5,201)\end{array}$ & $<.001$ & & & \\
\hline & Hours of study & & & & .25 & 3.927 & $<.001$ \\
\hline & Clarity & & & & .22 & 3.353 & .001 \\
\hline & Course & & & & -.19 & -3.031 & .003 \\
\hline & Repair & & & & .156 & 2.345 & .02 \\
\hline & Hallucinogens-F12 & & & & -.136 & -2.16 & .032 \\
\hline
\end{tabular}

In Step 2, 34.9\% of the variance of academic achievement was predicted by prior achievement (entrance examination grade) and, with less intensity, by satisfaction with academic progress. In this model, $R^{2}$ increased from .247 to .349 , a difference with the previous $R^{2}$ of $.101, F(1,199)=30.942, p<.05$.

With regard to university satisfaction, Step 5 accounted for $23.1 \%$ of its variance through the variables - from greater to lesserintensity_hours of study, Clarity, academic course, Repair, and the frequency of consumption of hallucinogens in the past year. In this model, $R^{2}$ increased from .143 to .231 , a difference with the $R^{2}$ of the first model of .088, and the increases of $F$ in all the models were significant at $<.05$. 


\section{DISCUSSION}

The results of this study supports the hypothesis of impact of students' personal variables (substance consumption, $\mathrm{El}$, and academic context) on university quality as assessed by its main indicators: achievement and satisfaction.

With regard to the consumption of psychoactive substances, our results are not consistent with prior works that found direct negative effects on academic success (Caso-Niebla \& Hernández-Guzmán, 2007; Musgrave-Marquart, Bromley, \& Dalley, 1997; Tejedor, 2003). However, consumption could have an indirect impact on satisfaction in the educational setting, just as it affects life satisfaction in general (Del Aguila, 2016).

With regard to $\mathrm{El}$, we observed a positive correlation between the Clarity and Repair dimensions and academic satisfaction. These dimensions explain part of satisfaction, so a possible indirect effect of $\mathrm{El}$ on academic achievement is supported (Extremera \& Fernández-Berrocal, 2003; Ferragut \& Fierro, 2012; Mega, Ronconi, \& De Beni, 2014; Serrano \& Andreu, 2016). Our results also argue that $\mathrm{El}$ is closely linked to greater life satisfaction in the university system, as also occurs in other scenarios (Anadón, 2006; Mikulic, Crespi, \& Cassullo, 2010).

With regard to academic context (prior performance, absenteeism, hours of study, and academic course), our results support that prior achievement (entrance examination grade) is the best predictor of university academic success (Latiesa, 1992; Rodríguez, Fita, \& Torrado, 2004). Moreover, academic success is closely linked to satisfaction, in the sense that students who are more successful are also more satisfied. This relation may be mediated by factors such as self-concept, self-esteem, and students' positive expectations about themselves and their academic skills (Álvarez et al., 2015; Urquijo, 2002). Regarding absenteeism, our results support the conclusions of previous works in the sense that class attendance is related to better achievement (Álvarez \& López,
2011; Garbanzo, 2007; García et al., 2000). On another hand, regarding the variable hours of study, the results indicate that it is related to satisfaction. In a similar vein to earlier works, students who are more dedicated to, absorbed by, and vigorous in their studies are more satisfied (Caballero, Abello \& Palacio, 2007; Green, Hood, \& Neumann, 2015). Lastly, the variable academic course may also have an impact on satisfaction. Our results are consistent with works showing that first-year students' satisfaction is greater than that of second-year students (Arena, Arnaboldi, \& Azzone, 2010).

These results allow us to conclude that students' personal factors affect the quality of university education. These determinants are predominantly susceptible to improvement through psychosocial intervention, for example, the implementation of workshops to improve El. Other determinants could be improved through institutional measures, for example, by increasing the availability of spaces and time in which students could study, and, lastly, through preventive health interventions to decrease the consumption of psychoactive substances. These and other measures would increase university students' levels of achievement and satisfaction and, thereby, the quality of the system.

We think it is interesting continue with this type of studies, including other degrees and universities. We also recommend taking into account other psychological, social, and pedagogic factors that may directly or indirectly affect students' achievement and satisfaction and therefore, the quality of the university system (Garbanzo, 2007; Martín del Buey \& Romero, 2003; Tejedor 2003).

To conclude, the results of this work support that some personal determinants such as consumption of psychoactive substances, El, and the academic context affect the quality of the university system, due to their influence on achievement and satisfaction. These determinants are predominantly susceptible to improvement. Hence, by intervening in them, we can improve the quality of the system.

This study has some limitations, for example, those associated with the use of self-reports 
for data collection, besides the limitations of the cross-sectional studies. We recommend expanding the sample and including other study populations in order to increase the representativeness and generalizability of the data.

\section{- Conflict of interest}

The authors declare no conflict of interest.

\section{REFERENCES}

Álvarez, P. R., \& López, D. (201 1). El absentismo en la enseñanza universitaria: un obstáculo para la participación y el trabajo autónomo del alumnado [Absenteeism in university education: an obstacle for students' participation and autonomous work]. Bordón. Revista de Pedagogía, 63(3), 43-56.

Álvarez, A., Suárez, N., Tuero, E., Núñez, J. C., Valle, A., \& Regueiro, B. (2015). Implicación familiar, autoconcepto del adolescente y rendimiento académico [Family involvement, adolescent's self-concept, and academic achievement]. European Journal of Investigation in Health, Psychology and Education, 5(3), 293-311.

Anadón, O. (2006). Inteligencia emocional percibida y optimismo disposicional en estudiantes universitarios [Perceived emotional intelligence and dispositional optimism in university students]. Revista Electrónica Interuniversitaria de Formación Del Profesorado, 9(1), 1-13.

Arena, M., Arnaboldi, M., \& Azzone, G. (2010). Student perceptions and central administrative services: The case of higher education in Italy. Studies in Higher Education, 35(8), 941 -959. doi: 10.1080/03075070903420708

Bobes, J., González, M. P., Sáiz, P. A., \& Bousoño, M. (1996). Índice europeo de severidad de la adicción: EuropASI. Versión española. Actas de La IV Reunión Interregional de Psiquiatría, 1996, 201-218.

Caballero, C. C., Abello, R., \& Palacio, J. (2007). Relación del burnout y el rendimiento académico con la satisfacción frente a los estudios en estudiantes universitarios [Relation of burnout and academic achievement to satisfaction with studies in university students]. Avances en Psicología Latinoamericana, 25(2), 98-111.

Caso-Niebla, J., \& Hernández-Guzmán, L. (2007). Variables que inciden en el rendimiento académico de adolescentes mexicanos [Variables that influence the academic performance of Mexican adolescents]. Revista Latinoamericana de Psicología, 39(3), 487-501.

Del Aguila, A. D. (2016). Afrontamiento y satisfacción con la vida en relación al consumo de sustancias de jóvenes universitarios [Coping and life satisfaction in relation to young university students' substance consumption]. Pontificia Universidad Católica del Perú: Lima.

Extremera, N., \& Fernández-Berrocal, P. (2003). La inteligencia emocional en el contexto educativo: hallazgos científicos de sus efectos en el aula [Emotional intelligence in the educational context: Scientific findings of its effects in the classroom]. Revista de Educación, 332, 97-116.

Fernández-Berrocal, P., \& Ruíz, D. (2008). La inteligencia emocional en la educación [Emotional intelligence in education]. Electronic Journal of Research in Educational Psychology, 6(15), 421-436.

Fernández-Berrocal, P., Alcaide, R., Domínguez, E., Fernández-McNally, C., Ramos, N. S., \& Ravira, M. (1998). Adaptación al castellano de la escala rasgo de metaconocimiento sobre estados emocionales de Salovey et al.: datos preliminares [Adaptation to Spanish of the Trait Meta-Mood Scale of Salovey et al: preliminary data]. In Libro de actas del V Congreso de Evaluación Psicológica (Vol. 1, pp. 83-84).

Ferragut, M., \& Fierro, A. (2012). Inteligencia emocional, bienestar personal y rendimiento académico en preadolescentes [Emotional intelligence, personal well-being, and academic achievement in preadolescents]. Revista Latinoamericana de Psicologia, 44(3), 95-104.

Garbanzo, G. M. (2007). Factores asociados al rendimiento académico en estudiantes 
universitarios, una reflexión desde la calidad de la educación superior pública [Factors associated with academic achievement in university students, a reflection from the quality of higher public education]. Revista Educación, 37(1), 43-63.

García, M. V., Alvarado, J. M., \& Jiménez, A. (2000). La predicción del rendimiento académico: regresión lineal versus regresión logística [The prediction of academic achievement: linear regression versus logistic regression]. Psicothema, 12(Suplemento), 248-252.

Gento, S., \& Vivas, M. (2003). El SEUE: un instrumento para conocer la satisfacción de los estudiantes universitarios con su educación [The SEUE: an instrument to learn about university students' satisfaction with their education]. Revista Acción Pedagógica, 12(2). Retrieved from http://www.saber.ula. ve/handle/123456789/17108

Gil-Olarte, P., Palomera, R., \& Brackett, M. A. (2006). Relating emotional intelligence to social competence and academic achievement in high school students. Psicothema, 18 Suppl., 118-123.

González-Arias, M. I., Carabantes Olivares, E., \& Muñoz-Carreño, N. E. (2016). Construcción y Validación de la Escala de Apreciación de la Calidad del Programa de Asignatura: Propuesta para el Estudio de la Calidad de la Docencia. Formación Universitaria, 9(1), 77-90. doi: 10.4067/ S0718-50062016000100009

Grace, F. R. (2004) The relationship between student satisfaction and emotional intelligence among undergraduate students enrolled in nursing programs, Doctoral Dissertation. Walden University: Minneapolis.

Green, H. J., Hood, M., \& Neumann, D. L. (2015). Predictors of Student Satisfaction with University Psychology Courses: A Review. Psychology Learning \& Teaching, 14(2), 131 146. doi: $10.1177 / 1475725715590959$

Hernando, Á., Oliva, A., \& Pertegal, M.Á. (2012). Family variables and academic achievement in adolescence. Estudios de Psicología, 33(1),5165. doi: $10.1174 / 021093912799803791$
Johnson, G. M., \& Buck, G. H. (1995). Students' Personal and Academic Attributions of University Withdrawal. Canadian Journal of Higher Education, 25(2), 53-77.

Latiesa, M. (1992). La deserción universitaria [College dropout]. CIS, Madrid. GIROUX, H.(1992): Teoría Y Resistencia En Educación. Madrid: Siglo XXI Editores.

Martín del Buey, F., \& Romero, M. E. (2003). Influencia de las expectativas en el rendimiento académico [The influence of expectations on academic achievement]. Aula abierta, (81), 99-110.

McKenzie, K., \& Schweitzer, R. (2001). Who succeeds at university? Factors predicting academic performance in first year Australian university students. Higher Education Research \& Development, 20(1), 21-33. doi: 10.1080/07924360120043621

Mega, C., Ronconi, L., \& De Beni, R. (2014). What makes a good student? How emotions, self-regulated learning, and motivation contribute to academic achievement. Journal of Educational Psychology, 106(1), 121-131. doi: $10.1037 / a 0033546$

Mestre, J. M., Gutiérrez, J. M., Guerrero, C., and Guil, R. (2017). Gestión de emociones en el día a día [Management of emotions in day to day]. Madrid: Pirámide.

Mikulic, I. M., Crespi, M. C., \& Cassullo, G. L. (2010). Evaluación de la inteligencia emocional, la satisfacción vital y el potencial resiliente en una muestra de estudiantes de psicología [Assessment of emotional intelligence, life satisfaction and potential in a resilient sample of psychology students]. Anuario de Investigaciones, 17, 169-178.

Moral, M. de la V., Rodríguez, F. J., \& Ovejero, A. (2010). Correlatos psicosociales del consumo de sustancias psicoactivas en adolescentes españoles [Psychosocial correlates of psychoactive substance consumption in Spanish adolescents]. Salud Pública de México, 52(5), 406-415.

Musgrave-Marquart, D., Bromley, S. P., \& Dalley, M. B. (1997). Personality, Academic Attribution, and Substance Use as Predictors of Academic Achievement in College Students. 
Journal of Social Behavior and Personality; Corte Madera, CA, 12(2).

Pérez, N., \& Castejón, J. L. (2007). La inteligencia emocional como predictor del rendimiento académico en estudiantes universitarios [Emotional intelligence as a predictor of academic performance in university students]. Ansiedad y Estrés, 13(1), 121-131.

Pritchard, M. E., \& Wilson, G. S. (2003). Using Emotional and Social Factors to Predict Student Success. Journal of College Student Development, 44(1), 18-28. doi:10.1353/ csd.2003.0008

Rodríguez, S., Fita, E., \& Torrado, M. (2004). El rendimiento académico en la transición secundaria-universidad [Academic achievement in the secondary schooluniversity transition]. Revista de Educación, 334, 391-414.

Salovey, P., Mayer, J. D., Goldman, S. L., Turvey, C., \& Palfai, T. P. (1995). Emotional attention, clarity, and repair: Exploring emotional intelligence using the Trait MetaMood Scale. En Emotion, disclosure, and health (Pennerbarker J. W., pp. 125-154). Washington, D. C.: American Psychological Assn.

Serrano, C., \& Andreu, Y. (2016). Inteligencia emocional percibida, bienestar subjetivo, estrés percibido, engagement y rendimiento académico en adolescentes [Perceived emotional intelligence, subjective well-being, perceived stress, engagement and academic achievement in adolescents]. Revista de Psicodidáctica, $21(2)$, 357-374. doi: 10.1387/RevPsicodidact. 14887

Tejedor, F. (2003). Poder explicativo de algunos determinantes del rendimiento en los estudios universitarios [Explanatory power of some determinants of performance in university studies]. Revista Española de Pedagogía, 61 (224), 5-32

Tessema, M. T., Ready, K., \& Yu, W. (2012). Factors affecting college students' satisfaction with major curriculum: Evidence from nine years of data. International Journal of Humanities and Social Science, 2(2), 34-44.

Thompson, C. (2013). Emotional intelligence and graduate student satisfaction at online institutions of higher education, Doctoral Dissertation. Walden University, Minneapolis. Retrieved from http:// scholarworks.waldenu.edu/cgi/viewcontent. cgi? article $=2053 \&$ context $=$ dissertations .

Urquijo, S. (2002). Auto-concepto y desempeño académico en adolescentes: relaciones con sexo, edad e institución [Self-concept and academic performance in adolescents: relationship to sex, age, and institution]. Psico-USF, 7(2), $211-218$.

Weerasinghe, I. S., Lalitha, R., \& Fernando, S. (2017). Students' Satisfaction in Higher Education Literature Review. American Journal of Educational Research, 5(5), 533-539. doi:10.12691/education-5-5-9 